\title{
Does Workforce Innovation Mediate the Relationship between Internal Factors and Performance in Malaysian Entrepreneurial SMEs?
}

\author{
Indra Devi Subramaniam ${ }^{1} \&$ Mohammad Mehdi Moslehi ${ }^{1}$ \\ ${ }^{1}$ Graduate School of Management, Jalan Multimedia, Cyberjaya, Malaysia \\ Correspondence: Indra Devi Subramaniam, Graduate School of Management, Jalan Multimedia, 63100 \\ Cyberjaya, Malaysia. Tel: 60-3-8312-5716. E-mail: indra@mmu.edu.my
}

Received: April 1, 2013 Accepted: April 28, 2013 Online Published: June 28, 2013

doi:10.5539/ass.v9n9p45 URL: http://dx.doi.org/10.5539/ass.v9n9p45

\begin{abstract}
This paper investigates the relationship between internal factors, workforce innovation and performance on entrepreneurial small and medium sized enterprises in Malaysia. The internal factors are transformational leadership, rewards, autonomy and empowerment and innovative supportive climate. An empirical analysis is based on data for 92 small and medium-sized enterprises (SMEs) in Malaysia. The results indicate that workforce innovation and performance is higher in entrepreneurial SMEs with high degree of transformational leadership, rewards, autonomy, empowerment and innovative supportive climate. Furthermore, the findings of this paper support the view that workforce performance of entrepreneurial SMEs will be better if they improve the relationship between transformational leadership and rewards with workplace innovation.
\end{abstract}

Keyword: workforce innovation, internal factors, performance, entrepreneurial SMEs, Malaysian

\section{Introduction}

\subsection{Introduction to the Problem}

Innovation and entrepreneurship are complementary of each other (Zhao, 2005). Both are essential for organizational prosperity and sustainability. Today, entrepreneurial companies have realized that focusing on organizational innovation can lead to creation of wealth and value for the company (Ireland, Hitt, Camp, \& Sexton, 2001). Boosting entrepreneur organization through development of workforce innovation is a vital fact that does not happen overnight. Indeed, innovation can be changed to a core competency of the organizations when it is visioned by leaders in the organizational environment generally and by employees in their actions individually. Innovation is often performed by low and middle levels of management or employees directly. It is rarely done by leaders or top managers directly (Elenkov \& Manev, 2005).

Sometimes there is not enough substructure or supportive process of sharing or applying ideas inside the organization. This problem happens when new small businesses or entrepreneurial companies neglect to support innovational factors in their workforce in the growth stage of Venture's life cycle. According to Kuratko (2009), around 85 percent of all small start-up firms fail in the first year of starting. Companies must innovate as an absolute requirement to achieving high level of organizational performance (Morales et al., 2006). When leaders do not pay adequate attention to increasing the innovation capacity in their workforce and do not have any strategy to nurture and develop the innovation capacity in the organization, organizational performance becomes weak, profit decreases and as a result the organization experiences slow growth. Hence, such organizations decline or die because innovation has been respected more by their competitors.

\subsection{Importance of the Problem}

This research is conducted to address this potential problem. What should an entrepreneur company do to constantly inject freshness in their businesses, especially in the first years of its establishment? How can companies increase the productivity and performance through development of innovative workforces? The aim of this research is to find out useful ways to facilitate improvement of innovative behavior and performance among the workforce. Therefore, this study is trying to identify useful factors that leaders can use to create innovative behavior among workforces that would lead to an increase in individual and organizational 
performance. This study targets small and medium entrepreneurial companies to find practical solutions to make innovation an integral part of organizational climate and culture. It aims to increase added-value to the organizations through emphasizing the workforce innovation.

The paper is structured as follows. The following section reviews the literature on internal factors (transformational leadership, rewards, autonomy and empowerment, innovative supportive climate) workforce innovation and performance and illustrates the research hypotheses. The data and methodology section describes the data and the empirical methodology. The empirical results section provides the findings, whereas the discussion section contains the discussion of results. The final section formulates the concluding remarks.

\subsection{Review of Literature and Hypothesis Development}

\subsubsection{Creativity and Innovation}

Creativity is defined as presenting useful and new ideas. The definition of innovation is complementary to that of creativity. Innovation is about implementing useful and new ideas. It is about applying creative ideas in reality (Gumusluog lu \& Ilsev, 2009; Kuratko, 2009; Rank et al., 2004). Creativity has been identified as one of the principle sources of competitive advantage inside an organization. Creativity is emphasized when the firm wants to produce a product or provide a service differently from competitors (Cook, 1998). For many years, the R\&D department's activities have been related to technical innovation (Miller \& Morris, 1999). Many organizations or institutions invest on R\&D departments as official-expected and as basic centers of innovation places to innovate and control their activities there. But innovation is not necessarily technical and there are many examples of economic and social innovations that show that this belief is not correct (Drucker, 1994).

Indeed, in this competitive world with increasing rapid change, depending solely on R\&D departments is not sufficient and it does not guarantee organizational survival. Many useful innovations, regardless of their types, radical or incremental (Zhao, 2005), administrative or technological (Cooper, 1998), have been initiated from outside the boundaries of the R\&D department (Huff, Fredberg, Moeslein, Piller \& Gratton, 2006). R\&D function should not be the only source of innovation, especially for those small-medium enterprises that do not have R\&D departments or do not have enough capital to invest on R\&D departments. But all the workforce in every department of the organization can be prominent sources of innovation. It needs leaders to increase their understanding of the innovation process and learn to manage resources and provide facilities to improve the process of generating and implementing ideas two core steps in the course of individual innovative behavior (Axtell, et al., 2000). An organizational capacity to innovate and achieve future goals is dependent on the leader's ability to organize resources. Seven sources exist that provide opportunities that lead to innovation. One of them is invention. Invention leads to innovation. Therefore, innovation has more value than invention. (Drucker, 1994). Continuous innovation in all aspects (including products and services, processes, structure and routines) and also the ability to compete productively in the dynamic global market is a requirement that leaders see as an important determinant to capture the global environment's opportunities. However, innovation is hard to grasp and measuring the innovation in an organization is difficult, and finding suitable measurements to promote the innovation capacity is also hard (Huff et al., 2006).

But what is clear is the fact that putting creativity and innovation in organizational culture leads to seizing opportunities in competitive landscape and the production of new or developed products or services that competitors do not have ability to imitate in the short term. Thus, it will bring in a high degree of credit and value for the organization and will enhance organizational performance. Organizations are increasing their efforts to develop a stronger organizational culture which can drive innovation. They recruit, select, retain and motivate their employees based on the employees' ability of bringing up unique and creative ideas. They know innovation is a responsibility of each employee. However, it is a fact that hiring people who can continuously think creatively and are able to generate new ideas today is difficult (Zhao, 2005).

\subsubsection{Small-Medium Enterprise}

Small-Medium Enterprises (SMEs) are organizations in which the annual sale turnover and number of staff are within a certain limit. These limits may be a little different among countries. In Malaysia, based on these two criteria, enterprises are categorized in three groups: Micro, Small and Medium. National SME Development Council (NSDC) in 2005 approved a standard definition of SMEs in Malaysia to avoid different interpretations. It embraces four sectors:
1) Primary agriculture
2) Manufacturing
3) Manufacturing -related services (MRS) 
4) Services

Table1. SMEs definition on the basis of employees' numbers

\begin{tabular}{|c|c|c|c|c|c|c|}
\hline & \multicolumn{4}{|c|}{ Primary Agriculture } & $\begin{array}{c}\text { Manufacturing (including Agro-Based) } \\
\text { \& MRS }\end{array}$ & $\begin{array}{l}\text { Services Sector (including } \\
\text { ICT) }\end{array}$ \\
\hline Micro & Less than & $5 \mathrm{en}$ & loye & & Less than 5 employees & Less than 5 employees \\
\hline Small & $\begin{array}{l}\text { Between } \\
\text { employees }\end{array}$ & & $\&$ & & Between 5 \& 50 employees & Between 5 \& 19 employees \\
\hline Medium & $\begin{array}{l}\text { Between } \\
\text { employees }\end{array}$ & & & & Between $51 \& 150$ employees & $\begin{array}{lll}\begin{array}{l}\text { Between } \\
\text { employees }\end{array} & 20 \quad \&\end{array}$ \\
\hline
\end{tabular}

Source: National SME Development Council (NSDC), (2005)

Table 1 presents the detailed definitions of SMEs in three groups in Malaysia. According to the SME annual report 2012, 99.2\% of all businesses in Malaysia have been established by SMEs and it helps Malaysia's new economic model to become a high-income economy in the near future. This report anticipates that the contribution of SMEs in Gross Domestic Product (GDP) will increase from 32 percent in 2005 to 37 percent in 2010. It is also expected that exports will increase from 19 percent to 22 percent and employment to 57 percent in 2010. Appreciating the principle role of SMEs, the government has allocated RM3 billion in 2008 to implement 202 programs and RM3.04 billion in 2009 to implement 174 programs in order to support SMEs and raise their capability and capacity.

\subsubsection{Entrepreneurship, Innovative Behavior and Entrepreneur Organization}

Entrepreneurship is not just about creating novel business. Entrepreneurship is about creating new resources in order to produce new products or services and/or combining existent resources in new form to create new-developed products or services and commercialize them (Ireland et al., 2001). Kuratko (2009) has another definition for entrepreneurship. He defines entrepreneurship as a process involving the creation and implementation of novel ideas and creative-based solutions by engaging vigor and passion. He has also indicated that four parameters have impact on accomplishing the process of entrepreneurship: individual, organization, environment and process.

Bringing up the right idea at the suitable time and in proper market is the key concern of successful entrepreneur companies (Kuratko, 2009). Entrepreneur companies are more risk takers and are eager to change and have more motivation to achieve compared with small-medium enterprises. Entrepreneur companies have a critical contribution to increase economic performance through many ways including creating job opportunities, leadership and management style, giving importance to innovation and ensuring the effectiveness of research and development activities (Kuratko, 2009).

Smaller entrepreneur firms including small businesses established by women, immigrants or even minorities that have a principle contribution to economic development by their performance (Kuratko, 2009). Although smaller or medium entrepreneurial firms employ a small number of employees at first their importance to technological trends and increase in productivity will enable them to earn millions of dollars.

Innovation and entrepreneurship go hand in hand with each other and both are needed to sustain organizations in the rapid changing business environment (Zhao, 2005). Schumpeter (1934) is the first researcher who investigated a relationship between entrepreneurship and innovation. He concluded that it is an entrepreneur who produces innovation and this innovation will lead to growth of the economy. Fang Zhao (2005) showed there is a strong and complementary relationship between entrepreneurship and innovation that leads to growth and development of the organization.

\subsubsection{Transformational Leadership and Workforce Innovation and Performance}

According to the literatures reviewed, a large number of factors influence innovation. Leadership style is one of the most important factor (Jung et al., 2003; Mumford \& Gustafson, 1988). Transformational leadership, which has been found to have a more constructive approach on employees behavior, has been more popular in the literatures on innovation (Jung et al., 2003). Jung et al. (2003) tested the role of leaders in boosting organizational innovation. They focused on one aspect of leadership's style, transformational leadership. They proposed that leaders can affect employees in various ways, by defining and forming the context of work and by 
sharing organizational vision among organizational members. This affects the long-term organizational outcomes and employees' decisions and activities. Schein (1992) portrayed leaders as impressive individuals in the organizational culture. They can provide an appropriate system to encourage and increase the level of creativity and innovation among employees through strengthening and reinforcing knowledge, skills and abilities of employees.

Jung et al. (2003) pointed out that there is a positive relationship between transformational leadership and organizational innovation. This view is reinforced by empirical studies conducted by several researchers (Shin et al. 2003; Sosik et al., 2004; Elenkov et al. 2005; Morales et al., 2006). In another recent study, Sarros et al. (2008) focused on the relationship between transformational leadership and climate for innovation in organization. This empirical study was implemented among 1158 managers of private sector organizations in Australia. After testing the theoretical model, they concluded that the linkage is positive and transformational leadership has a significant contribute to innovative climate in the organization. The findings of Sarros et al. (2008) was consistent with findings of Shin et al. (2003), García-Morales, Montes \& Verdú-Jover (2006), Elenkov et al. (2005) and Gumusluog lu and Ilsev (2009). Based on the prominent role of the leader in the development of innovative workforces, Hypothesis 1 is one of the important hypotheses:

Hypothesis 1a: There is a positive relationship between transformational leadership and workforce innovation

Hypothesis 1b: There is a positive relationship between transformational leadership and workforce performance.

\subsubsection{Rewards and Workforce Innovation and Performance}

Many researchers have referred to rewards as a main factor in developing the creativity and innovation spirit among workforces. Walton (2003) in his research demonstrated some ways, including rewarding creative actions in order to emphasize on creative contributions in the organization. Jong and Hartog (2007) provided a collection of leader behaviors including 13 factors. These factors, including reward, have an influential impact on developing level of workforce innovation. Jong and Hartog (2007) showed that when financial or material rewards are provided, innovative performance of employees are increased.

Yukl (2002) provided a taxonomy of managerial practices. In this taxonomy, he prepared 14 leader behavior types with their description in a classified manner. It is relevant to what leaders do in their daily work. He indicated that these 14 types of leader behavior have significant impact on workforces' work behavior. Yukl (2002) mentioned that reward is one of managerial tools that effectively affect the performance of workforces and in general, organizational performance. Tangible rewards like increasing pay, promotion, or pay for performance are examples that Yukl (2002) explained. Kuratko (2009) has recommended rewarding as one of five steps that leaders can adapt their organizational policies and culture in order to promote the innovative and entrepreneurial spirit among organization members.

Given the considerable evidence, rewarding creative-based employees' activities or providing a reward system, are proposed as a useful and constructive leader's tool to promote innovative behavior of organizational members. Thus,

Hypothesis 2a: Rewards is positively related to workforce innovation.

Hypothesis 2b: Rewards is positively related to workforce performance.

\subsubsection{Autonomy and Empowerment and Workforce Innovation and Performance}

Amabile, Conti, Coon, Lazenby \& Herron (1996) pointed to autonomy as a main determinant in enhancing the level of individual and organizational creativity. According to them, once an individual was allowed to apply an adequate degree of autonomy in his/her work, creativity and innovation are promoted. Conversely, Damanpour (1991) found that when autonomy in decision making and empowerment are put in the hands of senior managers (called centralization) organizational innovation drops. According to George and Jones (2008), to support the innovation, it was recommended to establish an organic structure instead of mechanistic structure in the organization because it is more decentralized. Hence, people have more personal autonomy to perform their work and take risks. Also, by providing the organic structure, communicating is easier and innovation has more desired value. Hence, designing an appropriate organizational structure with considering adequate degree of individual autonomy can boost the level of innovation among employees and cause increased organizational efficiency. In another research, Zhao (2005) pointed out that a proper culture of empowerment as a factor of fostering interaction is essential for providing stimuli toward achieving two factors in an organization: entrepreneurial and innovative behavior.

In this situation, workers continually fear about the consequences of their risky decisions. It is in contrast to the 
philosophy of entrepreneurial companies that have substantial respect for risk taking behavior. Hence, based on findings of the literatures, this new hypothesis is proposed:

Hypothesis 3a: There is a positive relationship between autonomy and empowerment and workforce innovation.

Hypothesis 3b: There is a positive relationship between autonomy and empowerment and workforce performance.

\subsubsection{Innovative Supportive Climate and Workforce Innovation and Performance}

Organizational culture is the set of shared norms, values and beliefs that control the ways that organizational employees think, behave and interact with each other inside the organization and how they perceive and respond outside the organization (George \& Jones, 2008). In fact, a proper organizational culture, supported by a leader will increase employee cooperation and alliance and work as a determinant of employees' incentive to promote innovation and organizational effectiveness. Hence, knowing the ways to make organizational culture increase organizational innovation is required for organizational survival.

Improving innovation behavior and entrepreneurship in the organization is affected by two important factors: first, organizational culture and second, management style (Herbig et al., 1994; Zhao, 2005). In fact, it is not enough for a successful company to just engage in innovative behavior, but developing an adequate culture and supportive structure to maintain the workforce innovative behavior is an essence. In addition, innovation is spread in the entrepreneur organizations especially when it is visioned by leaders in the organizational environment and by employees in their initiative (Garcia-Morales et al., 2006).

Providing a supportive environment to support and nurture employees' ideas in the organization leads to creation of an innovative atmosphere in which employees as human capital are not afraid of sharing their ideas and taking risks. In line with this, Scott and Bruce (1994) conducted a survey among a large number of employees of a R\&D facility of a corporation in United State of America. After testing their model, Scott and Bruce (1994) found that between support for innovation and individual innovative behavior exist a positive association.

Research done by Jung et al. (2003), the relationship between two factors: innovative supportive climate and organizational innovation was tested. 32 electronic/telecommunication companies in Taiwan were investigated. They found a significant and positive link between innovative supportive climate and organizational innovation. They indicated that support for innovation is a major tool to provide a suitable atmosphere inside the organization. It helps to encourage employees to freely share their ideas and examine their innovative ideas.

Thus:

Hypothesis 4a: Innovative supportive environment is positively related to workforce innovation.

Hypothesis 4b: Innovative supportive environment is positively related to workforce performance.

\subsubsection{Workforce Innovation and Workforce Performance}

Growing and developing entrepreneur organization through improving innovative behaviors is a vital fact that does not happen overnight. Leaders of entrepreneur organizations must be dynamic and carefully pay attention to the organization's external environment, economical trends, globalization and the competitors' actions to maintain workforce performance and in general, organizational performance in a suitable level. For example, globalization means the tendency of companies to expand their business in new markets abroad. There are two main goals companies are pursuing when they decide to be global. One is expanding sales and another is cutting labor costs. When more globalization happens, the level of competition between competitors will increase and as a result, there will be increased world pressure to produce goods and services that are of lower cost and higher quality. Therefore, employees and employers must work harder and think smarter productively than they did already (Dessler, 2011). It implies that when a pressure to company like globalization goes up, consequently the workforce performance to neutralize this threat must increase.

Some researchers have demonstrated that encouraging workforces' innovation affects encouraging organizational performance (Hussain \& Idris, 2008; Garicia-Morales et al., 2006). Findings of an empirical study of Hurley \& Hult (1998) also showed a constructive relationship between organizational innovation and organizational performance. but in this study, the final goal was to show a relationship between individual innovation and individual performance of organizational members. In an exploratory study done by Jong et al. (2007) and based on reviewing literature and interviews with managers and/or entrepreneurs of 12 service firms, a practical list of 13 different leader behavior achieved incentives of innovative behavior among employees. Employee ability to innovate whether generating ideas or implementing ideas, increases individual performance and its consequences will boost the organization's ability to produce better products, provide greater services and improve the work 
process to develop business performance outcomes.

A comprehensive research by Cook (1998), reviewing a large number of literature, indicated that respect to creativity and innovation by organiazational members has benefits and substantial outcomes in three levels: individual, group and organizational. In fact, a few of investigated show clearly the link between personal innovation and personal performance. In the same year, Mumford, Marks, Connelly, Zaccaro, and Johnson (1998) using 1818 organizational leaders to measure divergent thinking, found that individual performance capabilities is influenced by the level of individual innovation. These findings is consistent with what Runco and Sakamoto (1999) have indicated in their book.

In reality, most of literature attempted to show that there are some certain factors affecting creative performance or innovative performance whether individually or organizationlly (Mumford, Scott, Gaddis \& Strange, 2002; Olham \& Cummings, 1996; Tierney, Farmer \& Graen, 1999; Woodman, Sawyer \& Griffin, 1993). They do not differentiate between creativity/innovation and performance in separate concepts. In other words, they have not focused on the relationship between innovation and performance. To understand whether individual innovation has meaningful effects on individual performance in the organization, it is hypothesized that:

Hypothesis 5: Workforce innovation is positively related to workforce performance.

Based on review of related literatures, a theoretical model is developed which is consistent with their findings. The theoretical model examines the influence of four factors on workforce innovation in order to answer research questions and objectives. In this framework, independent variables are transformational leadership, rewards, autonomy and empowerment and innovative supportive organizational climate for innovation. The independent variables directly influence workforce innovation and indirectly have influence on individual performance as a dependent variable. Workforce innovation aids to explain the relationship between the independent variables and workforce performance. Hence, it is a mediating variable. Hence:

Hypothesis 6: Workforce innovation mediates the relationship between internal factors and workforce performance.

$$
\text { Independent Variables Mediating Variable Dependent Variable }
$$

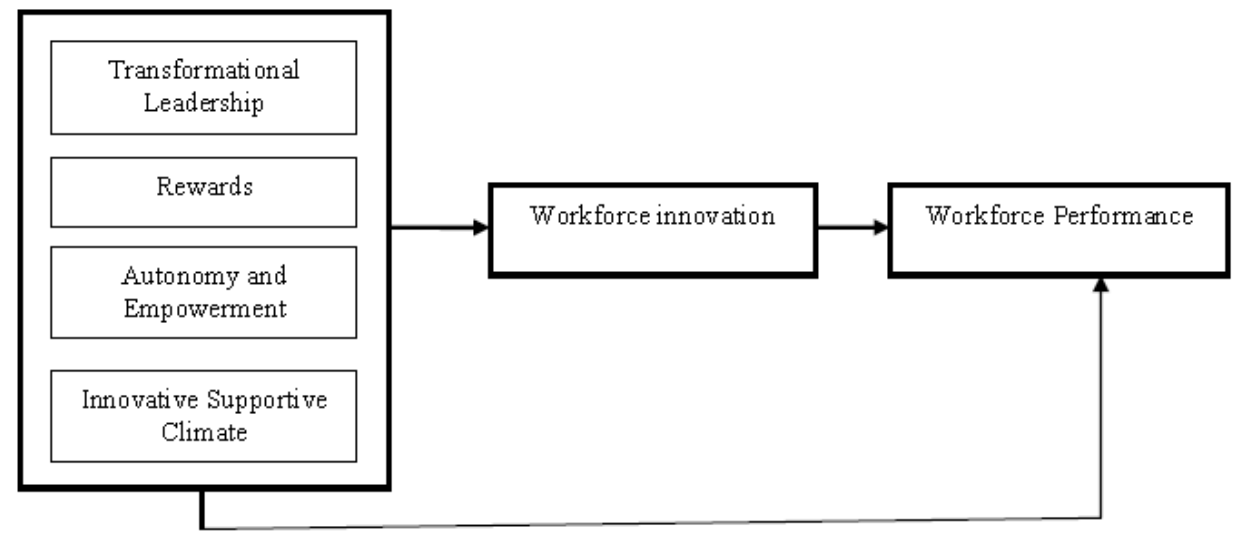

Figure 1. Theoretical framework of the relationship between internal factors, workforce innovation and workforce performance

Figure 1 presents the theoretical framework for this study.

\section{Method}

\subsection{Research Design}

This study uses the quantitative approach. It is a cross-sectional correlational study. The survey method is used to collect data.

\subsection{Research Instrument}

The research instrument used in this study is a structured questionnaire. The questionnaire has 4 sections. In section A, general information is gathered like age, gender, number of years that the employee has been employed, educational level and type of business. In this section, one question has more importance: number of employees in the organization. This question helps to determine the size of the organization whether it is small or medium. Section B has 22 statements and it is designed to collect the information about 4 factors that could 
influence the workforce innovation. There are 5 statements under "Leadership", 5 Statements under "Rewards", 5 items under "Autonomy and Empowerment" and finally, 8 items under "Innovative supportive organizational climate. Figure 2 presents items used to measure determinants of workforce innovation.

\begin{tabular}{|c|c|}
\hline $\begin{array}{l}\text { Section B: Factors Influencing } \\
\text { Workforce innovation }\end{array}$ & Statements \\
\hline \multirow{5}{*}{ Transformational Leadership } & $\begin{array}{l}\text { 1. The firm's leaders are always watchful for new opportunities for the } \\
\text { unit/department/organization. }\end{array}$ \\
\hline & 2. The firm's leaders have a clear common view of its final aims. \\
\hline & 3. The firm's leaders succeed in motivating the rest of the company. \\
\hline & 4. The firm's leaders always act as the organization's leading force. \\
\hline & $\begin{array}{l}\text { 5. The organization has leaders who are capable of motivating and } \\
\text { guiding their colleagues on the job. }\end{array}$ \\
\hline \multirow{5}{*}{ Rewards } & 1. My supervisor offers rewards me for my innovative contributions \\
\hline & 2. I am adequately rewarded for my performance \\
\hline & 3. I believe that the results of innovative behavior are shown in my pay. \\
\hline & $\begin{array}{l}\text { 4. In my job, my innovative efforts are taken into account when } \\
\text { determining formal rewards. }\end{array}$ \\
\hline & $\begin{array}{l}\text { 5. In my job, I feel there are many opportunities to win an incentive or a } \\
\text { reward }\end{array}$ \\
\hline \multirow{5}{*}{ Autonomy and Empowerment } & 1. In the main, I determine how I do my job. \\
\hline & 2. I am able to choose my own tools. \\
\hline & 3. I have flexibility in my working hours. \\
\hline & 4. I am able to decide my own work objective and/or methods. \\
\hline & $\begin{array}{l}\text { 5. I am able to develop and implement my own ideas for new ways of } \\
\text { doing my job. }\end{array}$ \\
\hline \multirow{8}{*}{ Innovative Supportive Climate } & 1. Creativity is encouraged here. \\
\hline & 2. Our ability to function creatively is respected by the organization. \\
\hline & $\begin{array}{l}\text { 3. Around here, people are allowed to try to solve the same problems in } \\
\text { different ways. }\end{array}$ \\
\hline & $\begin{array}{l}\text { 4. This organization can be described as flexible and continually } \\
\text { adapting to change. }\end{array}$ \\
\hline & $\begin{array}{l}\text { 5. We build on each other's ideas in order to achieve the best possible } \\
\text { outcomes. }\end{array}$ \\
\hline & 6. In my firm, assistance in developing ideas is readily available. \\
\hline & 7. There are adequate resources devoted to innovation in this firm. \\
\hline & 8. There is adequate time available to pursue ideas here. \\
\hline
\end{tabular}

Figure 2. The items to measure factors influencing workforce innovation

Section $\mathrm{C}$ is planned to solicit the workforce opinion about their level of innovation during last three years. It contains 6 items. The items to measure workforce innovation are presented in figure 3 . 


\begin{tabular}{|l|l|}
\hline Section C & \\
\hline \multirow{4}{*}{ Workforce innovation } & 1. My suggestions to improve current products or services have increased. \\
\cline { 2 - 3 } & 2. My suggestions to improve current work practices have increased. \\
\cline { 2 - 2 } & 3. I have increased my acquisition of new knowledge \\
\cline { 2 - 2 } & 4. In my job, I have actively contributed to changing the work organization. \\
\cline { 2 - 3 } & 5. I have found new approaches to execute my job tasks \\
\cline { 2 - 3 } & 6. I constantly search out new working methods, techniques or instruments \\
\hline
\end{tabular}

Figure 3. The items to measure workforce innovation

Section D contains 5 statements that have been designed to measure individual performance during last three years. The 5 statements to assess workforce performance are displayed in figure 3.3.

\begin{tabular}{|l|l|}
\hline Section D & \\
\hline \multirow{4}{*}{ Workforce performance } & 1. The quality of my work performance has increased \\
\cline { 2 - 3 } & 2. My work output has increased \\
\cline { 2 - 2 } & 3. I have received more praise for my work from my superiors \\
\cline { 2 - 3 } & 4. My performance appraisal scores have increased \\
\cline { 2 - 2 } & 5. My personal accountability for my work has increased \\
\hline
\end{tabular}

Figure 4 . The items to measure workforce performance

The respondents are required to give their response using a five point likert-like scale as follows:

$$
\begin{aligned}
& 1=\text { Strongly Disagree } \quad 2=\text { Disagree } \quad 3=\text { Neither agree nor disagree } \\
& 4=\text { Agree } \quad 5=\text { Strongly Agree }
\end{aligned}
$$

\subsection{Questionnaire Development}

\subsubsection{Transformational Leadership}

The first factor, transformational leadership, consists of 5 statements. It is based on a scale introduced by Podsakoff, Mackenzie, Moorman, and Fetter (1996) who studied many features of transformational leadership. Then, Garcia-Morales et al. (2006) used it in their research.

\subsubsection{Rewards}

The second factor is rewards. It refers to providing or recommending tangible rewards, such as a pay increase or promotion for effective performance, significant achievements, and demonstrated competence. It includes 5 statements. These items are a modified form of an instrument used by Jaworski and Kohli (1993) to measure rewards in their study..

\subsubsection{Autonomy and Empowerment}

A collection of five-item scale has been provided for measuring this factor. The source of this scale is an instrument used by Jackson, Wall, Martin, and Davids (1993) and Spreitzer (1995).

\subsubsection{Innovative Supportive Organizational Climate}

The last independent factor is innovative supportive organizational climate. In this research, a 7-item scale drawn from an original 22-item scale introduced by Scott and Bruce (1994) is used to measure whether the organization's climate supports innovation.

\subsubsection{Workforce Innovation}

The 5-item scale to measure workforce innovation has been adapted from one developed by Axtell et al. (2000). These items try to measure the progress of the workforce innovation in the last three years.

\subsubsection{Workforce Performance}

In this study, individual performance is operationalized as displaying work quality, work quantity, personal accountability, performance appraisal scores and receiving positive feedback from superiors. 


\subsection{Sampling}

Selecting an adequate sample size from the population numerically helps to identify the population characteristics significantly. A total of 102 SMEs were selected for this study. 2 or 3 employees were selected from the total number of employees in these enterprises as the respondents for this study. The structured questionnaire was distributed to these respondents. Only 92 useable completed questionnaires from 102 enterprises were returned to the researcher. It shows the participation among the enterprises is $90.2 \%$ and among the workforce is $84.38 \%$ which indicates a high response rate.

\subsection{Pilot Study}

The validity of the questionnaire was gauged using a panel of 6 experts comprising of management lecturers and senior managers. They checked the questionnaire for face and content validity. The Cronbach Alpha was used to determine the reliability of the questionnaire. The Cronbach alpha methods determines the reliability of the questionnaire by calculating the inter item correlation coefficients for each of the constructs in this study. Table 3.1 presents the Cronbach alpha values for each of the constructs i.e. transformational leadership, rewards, autonomy and empowerment and innovative supportive climate, workforce innovation and workforce performance. As shown in Table 2, all the Cronbach Alpha values are within the suitable range from 0.706 to 0.901 . This shows that the questionnaire has sufficient reliability to be used as the research instrument in the actual survey.

Table 2. Results of reliability test

\begin{tabular}{lc}
\hline Constructs & Cronbach Alpha \\
\hline Transformational Leadership & 0.815 \\
Rewards & 0.901 \\
Autonomy and Empowerment & 0.712 \\
Innovative Supportive Climate & 0.706 \\
Workforce Innovation & 0.841 \\
Workforce Performance & 0.841 \\
\hline
\end{tabular}

\subsection{Data Collection}

Data was collected by personally administering and collecting the questionnaire. This was to enable the researcher to clarify any questions regarding the items in the questionnaire as well as to increase the return rate of completed questionnaire.

\subsection{Data Analysis}

Both descriptive and inferential statistics were used to analyse the data. Descriptive statistics was used to describe the profile of the respondents. Inferential statistics in the form of regression analysis was used to test the research hypothesis. The level of significance was set at $\mathrm{p}=0.05$.

\section{Results}

\subsection{Profile of Respondents}

3.1.1 Distribution of Respondents by Type of Business

Table 3. Distribution of respondents by type of business

\begin{tabular}{lcc}
\hline Type of the business & Frequency & Percent \\
\hline Manufacturing/Engineering & 14 & 8.6 \\
IT/Telecommunication & 115 & 71.0 \\
Retail/Wholesale & 2 & 1.2 \\
Construction & 7 & 4.3 \\
Healthcare & 4 & 2.5 \\
Educational Institution & 12 & 7.4 \\
Other & 8 & 4.9 \\
Total & $\mathbf{1 6 2}$ & $\mathbf{1 0 0 . 0}$ \\
\hline
\end{tabular}


Table 3 presents the distribution of SMEs by type of business. A total number of 162 respondents returned completed useable questionnaires. With regard to the type of business, $8.6 \%$ of respondents were from the manufacturing/engineering sector. Around two third of respondents (71.0\%) were from the IT/telecommunication sector. Just $1.2 \%$ of the respondents were from retail/wholesale sector. $4.3 \%$ of respondents worked in the construction business. Just $2.5 \%$ of the respondents belonged to the healthcare business. $7.4 \%$ of respondents worked in the educational institutions and finally, $4.9 \%$ were from other types of business.

3.1.2 Distribution of Respondents by Size of organizations

Table 4. Distribution of respondents by size of organizations

\begin{tabular}{lcc}
\hline Total number of employee & Frequency & Percent \\
\hline Between 5 and 19 (small) & 100 & 61.7 \\
Between 20 and 50 (medium) & 55 & 34.0 \\
Greater than 51 (medium) & 7 & 4.3 \\
Total & $\mathbf{1 6 2}$ & $\mathbf{1 0 0 . 0}$ \\
\hline
\end{tabular}

Table 4 presents the distribution of organizations by size. A majority of organizations i.e. $61.7 \%$ belonged to the small sized enterprises. Furthermore, one third of the organizations (34\%), belonged to the medium sized enterprises. Only 7 or $4.3 \%$ of the organizations had number of employees greater than 51 and but less than 150 .

\subsection{Hypothesis Testing}

Is there a relationship between transformational leadership, rewards, autonomy and empowerment and innovative supportive climate with workforce innovation in entrepreneurial SMEs?

Results of examining the relationship between independent factors (transformational leadership, rewards, autonomy and empowerment, innovative supportive climate) and workforce innovation performed by multiple regression are presented in Table 5, Table 6 and Table 7. These results were used to test the following hypothesis:

$\mathrm{H} 1 \mathrm{a}$ : There is a positive relationship between transformational leadership and workforce innovation.

$\mathrm{H} 2 \mathrm{a}$ : Rewards is positively related to workforce innovation.

H3a: There is a positive relationship between autonomy and empowerment and workforce innovation.

H4a: There is a positive relationship between innovative supportive climate and workforce innovation.

Table 5. Model Summery Table of Predictors of Workforce innovation

\begin{tabular}{ccccccccccc}
\hline & \multicolumn{1}{c}{} & \multicolumn{4}{c}{ Change Statistics } \\
Model & R & R Square & Square & the Estimate & Change & Change & df1 & df2 & Change & Durbin-Watson \\
\hline 1 & $.695^{\text {a }}$ & .482 & .469 & .30763 & .482 & 36.573 & 4 & 157 & .000 & 1.626
\end{tabular}

a. Predictors: (Constant), Innovative Supportive Climate, Rewards, Transformational Leadership, Autonomy and Empowerment

b. Dependent Variable: Workforce innovation

In Table 5 , R-square value $=0.469$. It means $46.9 \%$ of the variation in workforce innovation can be predicted by variation in transformational leadership, rewards, autonomy and empowerment, and innovative supportive climate. It can be inferred that there are other predictors of workforce innovation that this study has not included. Durbin-Watson value $=1.626$ which has fall between 1.5 and 2.5. It implies that independence of residual is accepted in this model and there is no autocorrelation problem in the data. 
Table 6. ANOVA results of predictors of workforce innovation

\begin{tabular}{llrrrrr}
\hline Model & & Sum of Squares & df & Mean Square & F & Sig. \\
\hline 1 & Regression & 13.845 & 4 & 3.461 & 36.573 & $.000^{\text {a }}$ \\
& Residual & 14.858 & 157 & .095 & & \\
& Total & 28.703 & 161 & & & \\
& & & & & \\
\hline
\end{tabular}

a. Predictors: (Constant), Innovative Supportive Climate, Rewards, Transformational Leadership, Autonomy and Empowerment

b. Dependent Variable: Workforce innovation

Based on the ANOVA, table 6 , the p-value is $0.000<0.05$ Therefore at least one of the 4 predictor variables can be utilized to model workforce innovation.

Table 7. Coefficients table of predictors of workforce innovation

\begin{tabular}{|c|c|c|c|c|c|c|c|}
\hline \multirow[b]{2}{*}{ Model } & \multicolumn{2}{|c|}{$\begin{array}{l}\text { Unstandardized } \\
\text { Coefficients }\end{array}$} & \multirow{2}{*}{$\begin{array}{c}\text { Standardized } \\
\text { Coefficients } \\
\text { Beta }\end{array}$} & \multirow[b]{2}{*}{$\mathrm{t}$} & \multirow[b]{2}{*}{ Sig. } & \multicolumn{2}{|c|}{ Collinearity Statistics } \\
\hline & B & Std. Error & & & & Tolerance & VIF \\
\hline (Constant) & .964 & .248 & & 3.879 & .000 & & \\
\hline Transformational Leadership & .188 & .077 & .192 & 2.428 & .016 & .525 & 1.906 \\
\hline Rewards & .341 & .068 & .374 & 5.021 & .000 & .595 & 1.681 \\
\hline Autonomy \& Empowerment & .135 & .057 & .191 & 2.372 & .019 & .510 & 1.963 \\
\hline $\begin{array}{l}\text { Innovative Supportive } \\
\text { Climate }\end{array}$ & .085 & .085 & .094 & 1.003 & .318 & .374 & 2.675 \\
\hline
\end{tabular}

a. Dependent Variable: Workforce innovation

The results in table 7 show that there is a significant relationship between transformational leadership and workforce innovation ( $\mathrm{B}=0.188, \mathrm{p}<0.05)$, rewards and workforce innovation $(\mathrm{B}=0 \mathrm{p} .341, \mathrm{p}<0.05)$, autonomy and empowerment and workforce innovation $(\mathrm{B}=0.135, \mathrm{P}<0.05)$, while the relationship between innovative supportive climate and workforce innovation is not significant $(B=0.085, \mathrm{p}>0.05)$. Based on the results, H1a, $\mathrm{H} 2 \mathrm{a}, \mathrm{H} 3 \mathrm{a}$ are not rejected while $\mathrm{H} 4 \mathrm{a}$ is rejected.

Table 8. Stepwise multiple regressions: predictors of workforce innovation

\begin{tabular}{lcrrrrrrrr}
\hline & & \multicolumn{7}{c}{ Change Statistics } \\
Model & $\mathrm{R}$ & \multicolumn{1}{c}{$\begin{array}{c}\mathrm{R} \\
\text { Square }\end{array}$} & $\begin{array}{c}\text { Adjusted R } \\
\text { Square }\end{array}$ & $\begin{array}{c}\text { Std. Error of } \\
\text { the Estimate }\end{array}$ & $\begin{array}{c}\text { R Square } \\
\text { Change }\end{array}$ & F Change & df1 & df2 & Sig. F Change \\
\hline 1 & $.617^{\mathrm{a}}$ & .381 & .377 & .33331 & .381 & 98.366 & 1 & 160 & .000 \\
2 & $.670^{\mathrm{b}}$ & .449 & .442 & .31534 & .068 & 19.754 & 1 & 159 & .000 \\
3 & $.692^{\mathrm{c}}$ & .479 & .469 & .30764 & .030 & 9.061 & 1 & 158 & .003 \\
\hline
\end{tabular}

a. Predictors: (Constant), Rewards

b. Predictors: (Constant), Rewards, Autonomy and Empowerment

c. Predictors: (Constant), Rewards, Autonomy and Empowerment, Transformational Leadership

Table 8 presents the results of Stepwise Regression Analysis carried out to determine the significant predictors of 
workforce innovation. The results display that there are 3 significant predictors of workforce innovation. Reward alone explains $38.1 \%$ of the variation in workforce innovation. After that, autonomy and empowerment explains additional $6.8 \%$ of the variation in workforce innovation. All 3 predictors including reward, autonomy and empowerment and transformational leadership, together explain $47.9 \%$ of the variation in workforce innovation.

Is there a relationship between transformational leadership, rewards, autonomy and empowerment and innovative supportive climate with workforce performance in entrepreneurial SMEs?

The result of the multiple regression analysis between independent factors (transformational leadership, rewards, autonomy and empowerment, innovative supportive climate) and workforce performance are presented in Table 9, Table 10 and Table 11. These test the following hypothesis:

$\mathrm{H} 1 \mathrm{~b}$ : Transformational leadership is positively related to workforce performance.

$\mathrm{H} 2 \mathrm{~b}$ : Rewards are positively related to workforce performance.

$\mathrm{H} 3 \mathrm{~b}$ : Autonomy and empowerment is positively related to workforce performance.

H4c: Innovative supportive environment is positively related to workforce performance.

Table 9. Model summery table of predictors of workforce performance

Change Statistics

\begin{tabular}{|c|c|c|c|c|c|c|c|c|c|c|}
\hline & & & Adjusted R & Std. Error of & R Square & $\mathrm{F}$ & & & Sig. F & \\
\hline Model & $\mathrm{R}$ & R Square & Square & the Estimate & Change & Change & df1 & $\mathrm{df} 2$ & Change & Durbin-Watson \\
\hline & $.696^{\mathrm{a}}$ & .485 & .472 & .31786 & .485 & 36.970 & 4 & 157 & .000 & 1.910 \\
\hline
\end{tabular}

a. Predictors: (Constant), Innovative Supportive Climate, Rewards, Transformational Leadership, Autonomy and Empowerment

b. Dependent Variable: Workforce performance

In Table 9, R-square value $=0.472$. It means $47.2 \%$ of the variation in workforce performance can be predicted by variation in transformational leadership, rewards, autonomy and empowerment, and innovative supportive climate. It can be inferred that there are other predictors of workforce performance that this study has not included. Durbin-Watson value $=1.910$ which has fallen between 1.5 and 2.5. It implies that independence of residual is accepted in this model and there is no autocorrelation problem in the data.

Table 10. ANOVA table of predictors of workforce performance

\begin{tabular}{clrrrrr}
\hline Model & & Sum of Squares & df & Mean Square & F & Sig. \\
\hline 1 & Regression & 14.941 & 4 & 3.735 & 36.970 & $.000^{\mathrm{a}}$ \\
& Residual & 15.863 & 157 & .101 & & \\
& Total & 30.804 & 161 & & & \\
\hline
\end{tabular}

a. Predictors: (Constant), Innovative Supportive Climate, Rewards, Transformational Leadership, Autonomy and Empowerment

b. Dependent Variable: Workforce performance

Based on the ANOVA results presented in table 10 , the $p$-value is $0.000<0.05$. This means that at least one of the 4 predictor variables can be utilized to model workforce performance. The VIF of all predictor variables is less than 10 which implies there is no collinearity problem. 
Table 11. Coefficients table of predictors of workforce performance

\begin{tabular}{lccccccccc}
\hline & \multicolumn{2}{c}{$\begin{array}{c}\text { Unstandardized } \\
\text { Coefficients }\end{array}$} & \multicolumn{2}{c}{$\begin{array}{c}\text { Standardized } \\
\text { Coefficients }\end{array}$} & \multicolumn{4}{c}{$\begin{array}{c}\text { Collinearity } \\
\text { Statistics }\end{array}$} \\
& $\mathrm{B}$ & \multicolumn{2}{c}{ Std. Error } & Beta & $\mathrm{T}$ & Sig. & Tolerance & VIF \\
\hline 1 (Constant) & .837 & .257 & & 3.260 & .001 & & \\
Transformational Leadership & .289 & .080 & .285 & 3.608 & .000 & .525 & 1.906 \\
Rewards & .269 & .070 & .284 & 3.831 & .000 & .595 & 1.681 \\
Autonomy \& Empowerment & -.072 & .059 & -.098 & -1.224 & .223 & .510 & 1.963 \\
Innovative Supportive Climate & .295 & .088 & .315 & 3.360 & .001 & .374 & 2.675 \\
\hline
\end{tabular}

a. Dependent Variable: Workforce Performance

Furthermore, table 11 shows that the p-value of autonomy and empowerment equals to $0.223>0.05$, which means this factor is not a significant predictor of workforce performance. P-value for transformational leadership $(0.000)$ and rewards (0.000) and innovative supportive climate $(0.001)$ are less than 0.05 . Hence, these 3 variables (transformational leadership, rewards and innovative supportive climate) have positive significant relationship with workforce performance and they are determinants of workforce performance. Based on the results, $\mathrm{H} 1 \mathrm{~b}, \mathrm{H} 2 \mathrm{~b}, \mathrm{H} 4 \mathrm{~b}$ are not rejected while $\mathrm{H} 3 \mathrm{~b}$ is rejected.

Table 12. Stepwise multiple regressions: predictors of workforce performance

\section{Change Statistics}

\begin{tabular}{|c|c|c|c|c|c|c|c|c|c|}
\hline Model & $\mathrm{R}$ & R Square & $\begin{array}{l}\text { Adjusted R } \\
\text { Square }\end{array}$ & $\begin{array}{l}\text { Std. Error of } \\
\text { the Estimate }\end{array}$ & $\begin{array}{c}\text { R Square } \\
\text { Change }\end{array}$ & F Change & df1 & df2 & $\begin{array}{l}\text { Sig. F } \\
\text { Change }\end{array}$ \\
\hline 1 & $.606^{\mathrm{a}}$ & .368 & .364 & .34895 & .368 & 92.975 & 1 & 160 & .000 \\
\hline 2 & $.667^{\mathrm{b}}$ & .445 & .438 & .32789 & .078 & 22.218 & 1 & 159 & .000 \\
\hline 3 & $.693^{\mathrm{c}}$ & .480 & .470 & .31836 & .035 & 10.657 & 1 & 158 & .001 \\
\hline
\end{tabular}

a. Predictors: (Constant), Transformational Leadership

b. Predictors: (Constant), Transformational Leadership, Rewards

c. Predictors: (Constant), Transformational Leadership, Rewards, Innovative Supportive Climate

Table 12 presents the results of Stepwise Regression Analysis carried out to determine the significant predictors of workforce performance The results show that there are 3 significant predictors of workforce performance. Transformational leadership alone explains $36.8 \%$ of the variation in workforce performance. After that, reward explains an additional $7.7 \%$ of the variation in workforce performance, with innovative supportive climate contributing a further $3.5 \%$. All 3 predictors including transformational leadership, rewards and innovative supportive climate, together explain $48 \%$ of the variation in workforce performance.

Is there a Relationship between Workforce Innovation and Workforce Performance in Entrepreneurial SMEs?

A simple linear regression was carried out to determine the relationship between workforce innovation and workforce performance in SME and test hypothesis H5.

H5: Workforce innovation is positively related to workforce performance. 
Table 13. Model summery

\begin{tabular}{|c|c|c|c|c|c|c|c|c|c|c|}
\hline \multirow[b]{2}{*}{ Model } & \multirow[b]{2}{*}{$\mathrm{R}$} & \multirow[b]{2}{*}{ R Square } & \multirow[b]{2}{*}{$\begin{array}{l}\text { Adjusted R } \\
\text { Square }\end{array}$} & \multicolumn{7}{|c|}{ Change Statistics } \\
\hline & & & & $\begin{array}{l}\text { Std. Error of } \\
\text { the Estimate }\end{array}$ & $\begin{array}{l}\text { R Square } \\
\text { Change }\end{array}$ & $\begin{array}{c}\mathrm{F} \\
\text { Change }\end{array}$ & df1 & df2 & $\begin{array}{l}\text { Sig. F } \\
\text { Change }\end{array}$ & Durbin-Watson \\
\hline 1 & $.613^{\mathrm{a}}$ & .376 & .372 & .34665 & .376 & 96.347 & 1 & 160 & .000 & 2.112 \\
\hline
\end{tabular}

a. Predictors: (Constant), Workforce innovation

b. Dependent Variable: Workforce Performance

In Table 13, R-square value $=0.376$. It means just $37.6 \%$ of the variation in workforce performance can be predicted by variation in workforce innovation. It can be inferred that there are other predictors of workforce performance that this study has not included. Durbin-Watson value $=2.112$ which falls between 1.5 and 2.5 . This implies that independence of residual is accepted in this model and there is no autocorrelation problem in the data.

Table 14. ANOVA results on the relationship between workplace innovation and workplace performance

\begin{tabular}{llrrrrr}
\hline Model & & Sum of Squares & Df & Mean Square & F & \multicolumn{1}{c}{ Sig. } \\
\hline 1 & Regression & 11.578 & 1 & 11.578 & 96.347 & $.000^{\mathrm{a}}$ \\
& Residual & 19.227 & 160 & .120 & & \\
& Total & 30.804 & 161 & & & \\
\hline
\end{tabular}

a. Predictors: (Constant), Workforce innovation

b. Dependent Variable: Workforce performance

Based on the ANOVA results in table 14 , the p-value is $0.000<0.05$. This means workforce innovation is a significant predictor of workforce performance. Therefore, $\mathrm{H} 5$ is not rejected

Does innovative behavior of workforce mediate the relationship between the independent variables of transformational leadership, rewards, autonomy and empowerment and workforce performance?

To determine whether there is any relationship between independent variables (transformational leadership, rewards, autonomy and empowerment, and innovative supportive climate), and workforce innovation with workforce performance and to analyze the role of workforce innovation as a mediating factor, a new multiple regression analysis was done. This analysis tests hypothesis 6 which is as follows:

H6: The workforce innovation mediates the relationship between the independent variables of transformational leadership, rewards, autonomy and empowerment and innovative supportive environment and workforce performance.

Table 15. Model summery table of predictors of workforce performance considering workforce innovation

Change Statistics

Adjusted R Std. Error of R Square F $\quad$ Sig. F

Model R R Square Square the Estimate Change Change df1 df2 Change Durbin-Watson

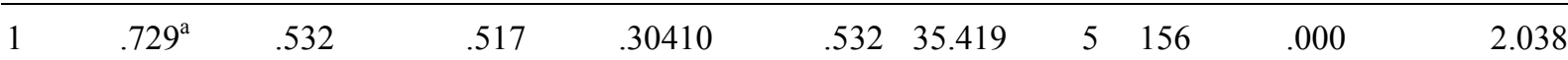

b. Dependent Variable: Workforce performance

The results of analysis are presented in Table 15. R-square value is 53 percent. Durbin-Watson value $=1.910$ which lies between 1.5 and 2.5. It implies that independence of residual is accepted in this model and there is no autocorrelation problem in the data. 
Table 16. ANOVA table of predictors of workforce performance considering workforce innovation

\begin{tabular}{llrrrrr}
\hline Model & & Sum of Squares & Df & Mean Square & \multicolumn{1}{l}{ F } & \multicolumn{1}{c}{ Sig. } \\
\hline 1 & Regression & 16.377 & 5 & 3.275 & 35.419 & $.000^{\mathrm{a}}$ \\
& Residual & 14.427 & 156 & .092 & & \\
& Total & 30.804 & 161 & & & \\
\hline
\end{tabular}

a. Predictors: (Constant), Innovative Supportive Climate, Rewards, Workforce innovation, Transformational Leadership, Autonomy and Empowerment

b. Dependent Variable: Workforce performance

Based on the ANOVA table 16 , the p-value is $0.000<0.05$. This means at least one of the 4 predictor variables considering workforce innovation can be utilized to model workforce performance.

Table 17. Correlation table of predictors of workforce performance considering workforce innovation

\begin{tabular}{lccccccccc}
\hline & \multicolumn{2}{c}{$\begin{array}{c}\text { Unstandardized } \\
\text { Coefficients }\end{array}$} & \multicolumn{2}{c}{$\begin{array}{c}\text { Standardized } \\
\text { Coefficients }\end{array}$} & \multicolumn{4}{c}{$\begin{array}{c}\text { Collinearity } \\
\text { Statistics }\end{array}$} \\
& Model & Std. Error & Beta & $\mathrm{t}$ & Sig. & Tolerance & VIF \\
\hline 1 (Constant) & .537 & .257 & & 2.089 & .038 & & \\
Workforce innovation & .311 & .079 & .300 & 3.941 & .000 & .518 & 1.932 \\
Transformational Leadership & .230 & .078 & .227 & 2.952 & .004 & .506 & 1.977 \\
Rewards & .163 & .072 & .172 & 2.251 & .026 & .512 & 1.951 \\
Autonomy and Empowerment & -.114 & .057 & -.155 & -1.990 & .048 & .492 & 2.033 \\
Innovative Supportive Climate & .269 & .084 & .287 & 3.187 & .002 & .371 & 2.692 \\
\hline
\end{tabular}

a. Dependent Variable: Workforce performance

Table 17 displays the correlation table of predictors of workforce performance considering workforce innovation. VIF of all predictor variables are less than 10 which implies there is no collinearity problem.

For there to be complete mediation by workforce innovation on the relationship between internal factors and workforce performance, the B values for the relationship between transformational leadership, rewards, autonomy and empowerment and innovative supportive climate and workforce performance should be zero when workforce innovation is regressed with them. This was not the case. However the $\mathrm{B}$ values were reduced for transformational leadership $(\mathrm{B}=0.289$ to $\mathrm{B}=0.230)$, rewards $(\mathrm{B}=0.269$ to $\mathrm{B}=0.163)$, autonomy and empowerment $(B=-0.072$ to $B=-0.114)$ and innovative supportive climate $(B=0.295$ to $B=0.269)$. One of coefficients' value which is related to autonomy and empowerment equals to -0.114 . This means that workforce innovation partially mediates the relationship between the internal factors and workforce performance.

Therefore H6 is only partially supported. Workforce innovation partially mediates the relationship between the transformational leadership, rewards, autonomy and empowerment and innovative supportive environment with workforce performance.

\section{Discussion}

The results on the relationship between independent variables and workforce innovation are consistent with previous studies. The relationships between transformational leadership and workforce innovation (Elenkov \& Manev, 2005; Gumusluog `lu \& Ilsev, 2009; Jung, et al., 2003; Morales, et al., 2006; Sarros, et al., 2008; Shin \& Zhou, 2003; Sosik, et al., 2004), rewards and workforce innovation (Jong \& Hartog, 2007; Walton, 2003; Yukl, 2002) and autonomy and empowerment and workforce innovation (Amabile, et al., 1996; George \& Jones, 2008; Zhao, 2005) are consistent with previous studies. The lack of correlation between innovative supportive climate and workforce innovation is consistent with that of Gumusluog $` l u$ and Ilsev (2009) who found a negative 
association between internal support climate for innovation and organizational innovation.

The results showed that transformational leadership, rewards and innovative supportive climate have a significant relationship with workforce performance. This is consistent with the findings by Jung et al. (2003) for transformational leadership and performance, Jong \& Hartog (2007), for rewards and performance and George and Jones (2008) and Yukl (2005) for innovative supportive climate and performance. However the study found that autonomy and empowerment did not have significant relationship with workforce performance This is contrary to the findings of George and Jones (2008). According to them a proper organizational culture, supported by a leader will increase employee cooperation and alliance and work as a determinant of employees' incentive to promote innovation and organizational effectiveness.

The study found that there is a significant relationship between workforce innovation and workforce performance. This is consistent with those of Hurley \& Hult (1998) and Mumford, Marks, Connelly, Zaccaro, and Johnson (1998).

The results showed that transformational leadership, rewards, autonomy and empowerment, and innovative supportive climate considering workforce innovation have significant but reduced relationships with workforce performance. Therefore workforce innovation partially mediates the relationship between these variables and workforce performance.

\section{Recommendations}

All organizations strive to acquire competitive advantage over their competitors. But in today's business, without having innovative behavior in human capital and proper strategies to activate the potential of employees, it is like an ambitious dream. Entrepreneur organizations always attempt to keep their members in an adequate level of innovative behavior to capture more market share. Large and international companies perform by producing new products or services based on innovative ideas. Entrepreneurial SMEs can also achieve success through innovation but with one difference. Actions of entrepreneurial SMEs, due to having smaller size compared with big sized organizations can achieve this more quickly.

For entrepreneurial SMEs to be able to grow and profit through innovation, the following recommendations are suggested:

1) Since one of main findings of this research showed the existence of the significant relationship between transformational leadership and workforce innovation and performance, leadership style should be more transformational for innovation. This means that entrepreneurial SMEs should be led by transformational leaders who can help to increase the innovativeness among the workforce by holding training or mentoring courses in enterprises or creating a constructive relationship with consulting companies and institutions outside the firm in enterprises which have limited internal resources.

2) In order to stimulate creativity and innovation inside the organization, planning and implementing a reward system is inevitable. Rewarding creative-based employees' activities results in enhancing organizational members to be innovative continuously and maintaining fresh ideas. It is a constructive tool in leaders' hands to promote innovative behavior among the workforce. Moreover, before the rewarding process, providing a feedback system to inform creators or innovators about results analyzing their actions is an additional effort to keep them confident and loyal to the organization.

3) Empowering the workforce and allowing them to develop their skills in a suitable work environment are vital to foster innovation behavior among them. Delegating appropriate power in selecting the ways of executing task, refraining from direct and intervening supervision, decentralizing authority of decision making cautiously in the organization level are some actions that leaders can take to increase individual and organizational innovation. However, since autonomy and empowerment do not have any influence on organizational performance, it is implied that willingness to power distance among Malaysian is relatively moderate. Some workforces of entrepreneurial SMEs prefer having control of top managers in their work process (Chow, Shields, \& Wu, 1999). This request is made by workforces when they are confused about the process of doing their tasks or when their task's goal is not clear for them (Jung, et al., 2003). In this case, transformational leaders should establish an adequate balance between delegating autonomy and empowerment and providing guidance for organizational members. Generally, setting clear innovation goals among members agreed by both management and employees is the best solution.

4) Although the review of literature has demonstrated a positive relationship between innovative supportive climate and individual innovation in this study, it was found that there is no significant relationship between innovative supportive climate and workforce innovation. One main reason can be due the lack of innovative 
support provided by entrepreneurial SMEs that were studied. The following suggestions are recommended to cope with this deficiency to provide an efficient climate for workforces in order to foster innovative behavior:

- Setting clear innovation goals among members agreed by both leader and employees

- Underlining personal responsibility like trust, obligation and confidence as assurance of innovative programs

- Not punishing failures and promoting risk taking spirit. Let individuals to test their ideas without being afraid of punishment. Indeed, failures are tools to more learning.

- Providing adequate time to pursue ideas.

- Providing financial resources for innovative programs and efforts.

- Enterprises should be more flexible and sequentially adapting to change

In conclusion, what should be considered by SMEs is that changes and fluctuation in technology, economy, policy and society are happening quickly. Today new ideas can be imitated by even the non serious competitors. Hence, organizations should engage in endeavors that shorten the process of converting from generating idea to implementing ideas. It is so important that these innovative ideas are converted to product or services and enter the market as soon as possible and the process of commercialization is performed as quickly as possible before the competitors can respond.

\section{References}

Amabile, T. M., Conti, R., Coon, H., Lazenby, J., \& Herron, M. (1996). Assessing the Work Environment for Creativity. Academy of Management Journal 39(5), 1154-1184. http://dx.doi.org/10.2307/256995

Axtell, C. M., Holman, D. J., Unsworth, K. L., Wall, T. D., Waterson, P. E., \& Harrington, E. (2000). Shopfloor innovation: facilitating the suggestion and implementation of ideas. Journal of Occupational \& Organizational Psychology, 73, 265-285. http://dx.doi.org/10.1348/096317900167029

Cook, P. (1998). The Creativity Advantage - Is Your Organization the Leader of the Pack? Industrial and Commercial Training, 30(5), 179-184. http://dx.doi.org/10.1108/00197859810225652

Cooper, R. J. (1998). A Multidimensional Approach to the Adoption of Innovation. Management Decision, 36(8), 493-502. http://dx.doi.org/10.1108/00251749810232565

Damanpour, F. (1991). Organizational Innovation: A meta-analysis of effects of determinants and moderators. Academy of Management Journa, 34, 555-590. http://dx.doi.org/10.2307/256406

Dessler, G. (2011). Human Resource Management. Singapore: Pearson Education, Inc.

Drucker, P. F. (1994). Innovation and Entrepreneurship: Practice and Principles Heinemann, London. London: Heinemann.

Elenkov, D. S., \& Manev, I. M. (2005). Top Management Leadership and Influence on Innovation: The Role of Sociocultural Context. Journal of Management, 31(3), 381-402. http://dx.doi.org/10.1177/0149206304272151

George, J. M., \& Jones, G. R. (2008). Understanding and Managing Organizational Behavior. New Jersey: Pearson Education, Inc.

Gumusluog \lu, L., \& Ilsev, A. (2009). Transformational Leadership and Organizational Innovation: The Roles of Internal and External Support for Innovation. Product, Innovation Management, (26), 264-277. http://dx.doi.org/10.1111/j.1540-5885.2009.00657.x

Herbig, P., Golden, J. E., \& Dunphy, S. (1994). The Relationship of Structure to Entrepreneurial and Innovative Success. Marketing Intelligence \& Planning, 12(9), 37-48. http://dx.doi.org/10.1108/02634509410069038

Huff, A. S., Fredberg, T., Moeslein, K., Piller, F. T., \& Gratton, L. (2006). Leading Open Innovation: Creating Centripetal Innovation Capacity. Paper presented at the Annual Meeting of the Academy of Management, Atlanta, Georgia.

Hurley, R. F., \& Hult, T. M. (1998). Innovation, Market Orientation, and Organizational Learning: an Integration and Empirical Examination. Journal of Marketing, 62, 42-54. http://dx.doi.org/10.2307/1251742

Hussain, N. H. B. M., \& Idris, A. (2008). Leadership Style, External Environment, Learning Climate and Innovation in Small and Medium Enterprises. Working Paper.

Ireland, R. D., Hitt, M. A., Camp, S. M., \& Sexton, D. L. (2001). Integrating Entrepreneurship Actions and 
Strategic Management Actions to Create Firm Wealth. Academy of Management Executive, 15(1), 49-63. http://dx.doi.org/10.5465/AME.2001.4251393

Jackson, P. R., Wall, T. D., Martin, R., \& Davids, K. (1993). New Measures of Job Control, Job Complexity, and Suggestion Contribution under Gainsharing plans. Journal of Applied Psychology, 78, 753-762. http://dx.doi.org/10.1037/0021-9010.78.5.753

Jaworski, B. J., \& Kohli, A. K. (1993). Market Orientation:Antecedents and Consequences. Journal of Marketing, 57(3), 53-70. http://dx.doi.org/10.2307/1251854

Jong, J. P. J. D., \& Hartog, D. N. D. (2007). How Leaders Influence Employees' Innovative Behaviour. European Journal of Innovation Management, 10(1), 41-64. http://dx.doi.org/10.1108/14601060710720546

Jung, D. I., Chowb, C., \& Wu, A. (2003). The Role of Transformational Leadership in Enhancing Organizational Innovation: Hypotheses and some Preliminary Findings. The Leadership Quarterly, 14, 525-544. http://dx.doi.org/10.1016/S1048-9843(03)00050-X

Kanter, R. M. (2004). The Challenge of Leadership. Emerald Group Publishing Limited, 20(6), 7-10.

Kuratko, D. F. (2009). Introduction to Entrepreneurship (8th ed.). South-western Cengage Learning.

Miller, W. L., \& Morris, L. (1999). Fourth Generation R\&D: Managing Knowledge, Technology, and Innovation. New York: John Wiley \& Sons.

García-Morales, V. J., Montes, F. J. L., \& Verdú-Jover, A. J. (2006). Antecedents and Consequences of Organizational Innovation and Organizational Learning in Entrepreneurship. Industrial Management \& Data System, 106(1), 21-42. http://dx.doi.org/10.1108/02635570610642940

Mumford, M. D., \& Gustafson, S. B. (1988). Creativity Syndrome: Integration, Application, and Innovation. Psychological Bulletin, 103(1), 27-43. http://dx.doi.org/10.1037/0033-2909.103.1.27

Mumford, M. D., Marks, M. A., Connelly, M. S., Zaccaro, S. J., \& Johnson, T. F. (1998). Domain Based Scoring of Divergent Thinking Tests: Validation Evidence in an Occupational Sample. Creativity Research Journal, 11, 151-164. http://dx.doi.org/10.1207/s15326934crj1102_5

Mumford, M. D., Scott, G. M., Gaddis, B., \& Strange, J. M. (2002). Leading Creative People: Orchestrating Expertise and Relationships. Leadership Quarterly, 13, 705-720. http://dx.doi.org/10.1016/S1048-9843(02)00158-3

Olham, G. R., \& Cummings, A. (1996). Employee creativity: personal and contextual factors at work. Academy of Management Journal, 39(3), 607-634. http://dx.doi.org/10.2307/256657

Podsakoff, P. M., Mackenzie, S. B., Moorman, R. H., \& Fetter, R. (1996). Transformational Leader Behaviors and Substitutes for Leadership Determinants of Employee Satisfaction, Commitment, Trust and Organizational Citizenship Behaviors. Journal of Managemet, 22, 259-298.

Rank, J., Pace, V. L., \& Frese, M. (2004). Three Avenues for Future Research on Creativity, Innovation, and Initiative. International Association for Applied Psychology, 53(4), 518-528. http://dx.doi.org/10.1111/j.1464-0597.2004.00185.x

Runco, M. A., \& Sakamoto, S. O. (1999). Experimental Studies of Creativity. In R. J. Sternberg (Ed.), Handbook of Creativity. Cambridge, England: Cambridge Univ. Press.

Sarros, J. C., Cooper, B. K., \& Santora, J. C. (2008). Building a Climate for Innovation Through Transformational Leadership and Organizational Culture. Journal of Leadership \& Organizational Studies, 15(2), 145-158. http://dx.doi.org/10.1177/1548051808324100

Schein, E. H. (1992). Organizational culture and leadership. San Francisco,CA: Jossey-Bass.

Schumpeter, J. (1934). The Theory of Economic Development. Cambridge, MA: Harvard University Press.

Scott, S. G., \& Bruce, R. A. (1994). Determinants of Innovative Behavior: A Path Model of Individual Innovation in the Workplace. Academy of Management Journal, 37(3), 580-607. http://dx.doi.org/10.2307/256701

Shin, S. J., \& Zhou, J. (2003). Transformational Leadership, Conservation and Creativity: Evidence from Korea. Academy of Management Journal, 46(6), 703-714. http://dx.doi.org/10.2307/30040662

Sosik, J. J., Jung, D. I., Berson, Y., Dionne, S., \& Jaussi, K. S. (2004). The Dream Weavers: Strategy-Focused Leadership in Technology-Driven Organizations. Greenwich: Information Age Publishing, Incorporated.

Spreitzer, G. M. (1995). Psychological Empowerment in the Workplace: Dimensions, Measurement, and 
Validation. Academy of Management Journal, 38(5), 1442-1465. http://dx.doi.org/10.2307/256865

Tierney, P., Farmer, S. M., \& Graen, G. B. (1999). An Examination of Leadership and Employee Creativity: the Relevance of Traits and Relationships. Personnel Psychology, 52, 591-620. http://dx.doi.org/10.1111/j.1744-6570.1999.tb00173.x

Walton, A. P. (2003). The Impact of Interpersonal Factors on Creativity. International Journal of Entrepreneurial Behaviour \& Research, 9(4), 146-162. http://dx.doi.org/10.1108/13552550310485120

Woodman, R. W., Sawyer, J. E., \& Griffin, R. W. (1993). Toward a Theory of Organizational Creativity. Academy of Management Review, 18(2), 293-321.

Yukl, G. (2002). Leadership in Organizations (5th ed.). Prentice-Hall, Englewood Cliffs, NJ.

Zhao, F. (2005). Exploring the synergy between entrepreneurship and innovation. International Journal of Entrepreneurial Behaviour \& Research In Organizational Behavior, 11(1), 25-41. $\mathrm{http}: / / \mathrm{dx}$.doi.org/10.1108/13552550510580825

\section{Copyrights}

Copyright for this article is retained by the author(s), with first publication rights granted to the journal.

This is an open-access article distributed under the terms and conditions of the Creative Commons Attribution license (http://creativecommons.org/licenses/by/3.0/). 